\title{
The effect of undernutrition on the establishment of pregnancy in the ewe
}

\author{
José-Alfonso Abecia $^{\mathrm{a} *}$, Cecilia Sosa ${ }^{\mathrm{a}, \mathrm{b}}$, Fernando ForCADA $^{\mathrm{a}}$, \\ Ana MEIKLE ${ }^{b}$ \\ ${ }^{a}$ Animal Production and Food Science, Faculty of Veterinary Medicine, Miguel Servet, \\ 177. 50013 Zaragoza, Spain \\ b Biochemistry, Faculty of Veterinary Medicine, Lasplaces 1550, Montevideo 11600, Uruguay
}

\begin{abstract}
The relationship between nutrition and reproduction in sheep has been the subject of research in several international groups. This review will particularly focus on the effects of undernutrition on the potential causes of reproductive failure including abnormalities of the ovum or the embryo, luteal inadequacy and failure of the supply of progesterone to the uterus, or the mechanisms involved in maternal recognition of pregnancy. The level of nutrition and peripheral progesterone concentrations are inversely related, and increased rates of embryo loss, associated with higher progesterone concentrations in ewes with low levels of nutrition have been reported. Undernutrition may act through changes in the distribution of progesterone in the endometrium. Thus, lower endometrial levels on day 5 of the cycle in ewes fed half of their maintenance requirements have been observed, providing a link between the known role of progesterone in embryo survival by the modulation of uterine function and the higher embryo losses found in undernourished ewes. The evidence of an effect of maternal nutrition on IFN $\tau$ secretion from the conceptus and of $\mathrm{PGF}_{2 \alpha}$ production from the uterus is presented. Moreover, undernutrition provokes a reduction in the sensitivity of the endometrium to progesterone that may affect embryo survival. Finally, a state of undernutrition induces changes in the endometrial sensitivity to steroid hormones at early stages of pregnancy that could adversely alter uterine environment to the detriment of embryo survival.
\end{abstract}

sheep / nutrition / reproduction / progesterone / embryo

\section{INTRODUCTION}

The relationship between nutrition and reproduction in sheep has been the aim of research of several international groups from the sixties, and has been reviewed on several occasions [1-6]. Many groups have furthered knowledge of the mechanisms by which nutrition modifies the reproductive performance of the flocks, from the classical concept of the "static" and "dynamic" effect of liveweight on litter size described by Coop [7] in Australia, to the introduc-

*Corresponding author: alf@unizar.es tion of the body condition (BC) score [8] and its link with changes in ovulation rate and fertility [9].

The techniques for the measurement of hormone levels (RIA, ELISA), together with laparoscopic and ultrasonography routines, to characterize follicular changes and ovulation rate, have been incorporated into these studies and have improved the understanding of the underlying mechanisms that determine reproductive performance. Biochemistry and molecular biology are now providing answers to many of the questions arisen during the last 40 years. 
Whilst early investigations focused on the effects of nutrition on the hypothalamic-pituitary axis, more recent studies have tested the hypothesis that nutritional signals (e.g. metabolic hormones) exert a direct effect at the ovarian level. Less research has been performed on the effect of undernutrition on the uterine environment that plays a major role in determining the success of the embryo in the maintenance of pregnancy. The present review will focus its attention on the effect of undernutrition on the mechanism of establishment of pregnancy, which is essential to the survival of the embryo. The potential causes of wastage include abnormalities of the ovum or the embryo, luteal inadequacy and failure of the supply of progesterone to the uterus, and failure of the systems of maternal recognition of pregnancy [2].

\section{UNDERNUTRITION IN RESEARCH}

Undernutrition means feeding the animals below their liveweight maintenance requirements (M). Typically, experiments designed to study the effects of nutrition on embryo survival have involved undernourished ewes which are fed, usually, to supply half of their requirements $(0.5 \mathrm{M})$. These are compared with the maintenance (M) or the $1.5 \mathrm{M}$ diet. Few pieces of work address underfeeding below this threshold, firstly, because lower levels of feeding cannot be applied for long periods without significant adverse effects and secondly, and as a consequence of this, because in some countries lower levels of nutrition are not permitted by legislation regulating experimentation. The duration of the treatments has differed, also, amongst studies. This is of considerable importance since "static" and "dynamic" effects of undernutrition may provoke different responses, but long term differences in intake result in changes in body condition i.e. the two effects are related. Most of the works discussed below have focused their attention on the level of dietary energy, although some experimental designs have been carried out to determine the effect of specific nutrients (protein, glucose, etc.). Moreover, on some occasions the experimental group has been overfed, because overfeeding has been postulated to induce embryo wastage.

The effect of different levels of dietary energy on embryo survival in sheep has been widely reported in the literature [1013]. Surprisingly, reduced rates of embryo survival have been reported consistently in both overfed [11] and underfed ewes [12-14]. However, it is important to note that apart from the magnitude and duration of the undernutrition, other experimental factors such as breed, age, body condition (BC) at the onset of the experiments and type and source of food differ between studies, making it difficult to compare the results and draw conclusions. Table I summarizes some of the main conclusions derived from the literature.

\section{EFFECTS OF NUTRITION ON FOLLICULAR DEVELOPMENT AND OOCYTE QUALITY}

Most reports have investigated the nutritional benefits -instead of the detrimental effects- on follicular development. The practice of "flushing" (short periods of improved nutrition prior to mating) has been widely used by farmers to increase fertility [5]. Several studies report a greater number of follicles of larger diameter, in high liveweight or high $\mathrm{BC}$ ewes compared with low liveweight/BC ewes [12,15-17]. In ewes fed $2 \mathrm{M}$ diets for 6 days before and during the emergence of the ovulatory wave, the increased concentrations of glucose, insulin and leptin are associated with increased numbers of follicles growing 
Table I. Effects of nutrition on selected events involved in the mechanisms of establishment of pregnancy in sheep.

\begin{tabular}{|c|c|c|c|}
\hline Event & Effect & Diet & Reference \\
\hline \multicolumn{4}{|l|}{ Follicle characteristics } \\
\hline Number of small follicles & Reduction & Ad libitum & {$[21]$} \\
\hline \multirow[t]{3}{*}{ Number of large follicles } & No effect & High vs. low intake & {$[21]$} \\
\hline & Increment & $2 \mathrm{M}$ (superovulation) & [33] \\
\hline & Reduction & $0.5 \mathrm{M}$ (no superovulated) & {$[33]$} \\
\hline \multirow[t]{2}{*}{ Oestrogen secretion } & No effect & $0.5 \mathrm{M}$ & {$[19,20]$} \\
\hline & Increment & High intake & [21] \\
\hline $\begin{array}{l}\text { Oestradiol/testosterone } \\
\text { secretion ratio }\end{array}$ & Reduction & Low intake & {$[21]$} \\
\hline \multicolumn{4}{|l|}{ Oocyte quality } \\
\hline & Reduction & $2.3 \mathrm{M}$ & [27] \\
\hline & Reduction & $0.5 \mathrm{M}$ & {$[25]$} \\
\hline & No effect & $0.5 \mathrm{M}$ & {$[5]$} \\
\hline & No effect & $0.5 \mathrm{M}$ & [33] \\
\hline & Reduction & Ad libitum & [26] \\
\hline & No effect & 0.7 and $1.3 \mathrm{M}$ & {$[28]$} \\
\hline \multicolumn{4}{|l|}{ Embryo development } \\
\hline Day 8 & Delay in development & $0.5 \mathrm{M}$ & {$[20]$} \\
\hline Day 9 & No effect & $0.5 \mathrm{M}$ & [39] \\
\hline Day 11 & Increased embryo mortality & $0.5 \mathrm{M}$ & {$[12]$} \\
\hline Day 15 & Increased embryo mortality & $0.5 \mathrm{M}$ & [39] \\
\hline Day 16 & No effect & 0.5 and $2 \mathrm{M}$ & [41] \\
\hline Day 21 & Increased embryo mortality & Low intake & [14] \\
\hline \multicolumn{4}{|c|}{ Interferon-tau secretion } \\
\hline Day 15 & Reduction & $0.5 \mathrm{M}$ & [39] \\
\hline Day 16 & No effect & Ad libitum-0.5 M & [26] \\
\hline \multicolumn{4}{|l|}{ Prostaglandin secretion } \\
\hline Day 15 & Increment & $0.5 \mathrm{M}$ & [39] \\
\hline Day 16 & Increment & $0.5 \mathrm{M}$ & [26] \\
\hline \multicolumn{4}{|l|}{ Oestradiol secretion } \\
\hline & Increment & $0.5 \mathrm{M}$ & [24] \\
\hline & No effect & Fasting & {$[22]$} \\
\hline \multicolumn{4}{|l|}{ Progesterone secretion } \\
\hline Corpus luteum in vitro & No effect (days $8,9,14$ ) & $0.5 \mathrm{M}$ & {$[20,32,19]$ respectively } \\
\hline \multirow[t]{3}{*}{ Jugular vein } & Reduction & High intake & {$[30,31]$} \\
\hline & Reduction & $2 \mathrm{M}$ & [33] \\
\hline & Reduction & Low intake & {$[10,11]$} \\
\hline Ovarian vein & No effect (days $5,8,10,15$ ) & $0.5 \mathrm{M}$ & {$[31,20,31,39]$ respectively } \\
\hline Ovarian artery & No effect & $0.5 \mathrm{M}$ & {$[20]$} \\
\hline \multicolumn{4}{|c|}{ Endometrial progesterone content } \\
\hline Day 4 & No effect & Ad libitum-0.5 M & {$[26]$} \\
\hline Day 5 & Reduction & $0.5 \mathrm{M}$ & [31] \\
\hline Day 9 & No effect & $0.5 \mathrm{M}$ & [39] \\
\hline Day 10 & No effect & $0.5 \mathrm{M}$ & {$[31]$} \\
\hline \multicolumn{4}{|c|}{ Endometrial progesterone receptors } \\
\hline Binding capacity & Reduction (day 5) & $0.5 \mathrm{M}$ & {$[53]$} \\
\hline \multirow[t]{2}{*}{ Immunoreactivity } & Reduction & $0.5 \mathrm{M}$ & [51] \\
\hline & No effect & $0.5 \mathrm{M}$ & [53] \\
\hline \multirow[t]{2}{*}{ mRNA content } & No effect (ipsilateral side) & $0.5 \mathrm{M}$ & [53] \\
\hline & Reduction (contralateral side) & $0.5 \mathrm{M}$ & [53] \\
\hline \multicolumn{4}{|c|}{ Endometrial oestrogen receptors } \\
\hline Binding capacity & Reduction (day 5) & $0.5 \mathrm{M}$ & [53] \\
\hline Immunoreactivity & No effect & $0.5 \mathrm{M}$ & {$[51,53]$} \\
\hline mRNA content & No effect & $0.5 \mathrm{M}$ & {$[52,53]$} \\
\hline
\end{tabular}


from 2 to $3 \mathrm{~mm}$ [18]. When the effect of undernutrition was investigated (1.5 vs. $0.5 \mathrm{M}$ ), no differences between groups were found for the mean number of oestrogenic follicles (secreting $>500 \mathrm{pg}$ oestradiol per follicle per hour) $[19,20]$. Similarly, Rhind and McNeilly [21] found no treatment difference in the number of large follicles $(>2.5 \mathrm{~mm})$, although they reported more small follicles $(1-2.5 \mathrm{~mm})$ in higher intake (ad libitum) than in lower intake ewes (M).

Ewes with high liveweights presented higher total ovarian content of oestradiol and inhibin [17] which is consistent with observations of lower oestradiol/testosterone ratio in the large oestrogenic follicles in low intake ewes [21]. In contrast, no differences on testosterone and oestradiol follicular secretion in vitro were found in follicles derived from ewes fed 1.5 and $0.5 \mathrm{M}$ diets $[19,20]$. Although Kiyma et al. [22] found no difference in plasma oestradiol after five days of fasting in ewes, Adams et al. [23] observed that nutritionally restricted ewes exhibited slower secretion of oestrogen, owing to a reduced rate of metabolic clearance of oestradiol, which may explain the higher peripheral plasma oestradiol levels observed in undernourished ewes [24].

The results of studies on the effect of the level of food intake on oocyte quality in sheep are contradictory, and most of the work has been done using the superovulated ewe model. Yaakub et al. [25] observed that low dietary intake altered oocyte morphology in both naturallyovulating and superovulating ewes. In contrast, Boland et al. [5] reported no differences in the morphology of oocytes collected from ewes offered $0.5 \mathrm{M}$ compared with $2 \mathrm{M}$ diets. However, Lozano et al. [26] reported a lower number of good quality oocytes and embryos per animal treated in superovulated ewes fed an ad libitum diet compared with ewes offered control $(1.5 \mathrm{M})$ or low energy $(0.5 \mathrm{M}) \mathrm{di}$ - ets, concluding that ad libitum diets are highly detrimental for superovulatory programs. This is consistent with the findings of McEvoy et al. [27] who observed that high feeding levels in superovulated ewes prior to ovulation reduced the proportion of ova developing to or beyond the expanding blastocyst stage after 7 day culture, and concluded that excessive feeding during follicular recruitment and oocyte maturation in superovulated ewes imparts a legacy of embryonic loss and developmental retardation. In a study designed to determine if the nutrition of the oocyte donor ewe influenced the success of somatic cell cloning, Merino ewes were fed at either a highor a low-nutrition level for 3-5 months before superovulation treatments and no differences were detected in the numbers of follicles aspirated, oocytes recovered, or oocytes of a quality suitable for cloning [28].

\section{EFFECTS ON LUTEAL FUNCTION AND PROGESTERONE SUPPLY TO THE UTERUS}

Lawson and Cahill [29] postulated that variations in the physiological range of peripheral progesterone concentrations due to management factors such as nutrition may induce asynchrony between the embryo and the uterus, resulting in the failure of pregnancy to be established. However, investigations of the role of progesterone in the mediation of these nutritional effects have produced contradictory results.

An inverse relationship between the level of nutrition and peripheral progesterone concentrations has been observed $[12,30,31]$. It has been reported that mean weights of individual corpora lutea are not affected by undernutrition [13, $20]$ and that in vitro secretion of progesterone by corpora lutea from both undernourished and control ewes collected at day 8 [20], 9 [32] and 14 [19] of the 
oestrous cycle, is similar. Overall, data are consistent regarding the nutritional level and the peripheral progesterone concentrations: lower circulating progesterone concentrations in ewes with a high level of nutrition have been reported [10,11,27,33]. While no effect of the lower progesterone levels on oocyte characteristics were found in overfed ewes [10,11,33], increased rates of embryo loss, associated with higher progesterone concentrations, have been reported in undernourished ewes $[10,11]$. Parr [34] demonstrated that ewes on high planes of nutrition had lower concentrations of peripheral plasma progesterone because of an increase in the metabolic clearance rate of progesterone, rather than to changes in the secretion rate of the hormone from the corpora lutea.

The anomalous relationships between plane of nutrition, circulating plasma progesterone concentrations and embryo survival raise a question about the role of progesterone in embryo survival and the value of circulating progesterone levels as a tool in the study of the relationships between nutrition and pregnancy. In fact, the absence of an association between progesterone levels and embryo mortality led Rhind et al. [35] to suggest that the elucidation of the role of progesterone on embryo wastage requires measurement of progesterone profiles in either the ovarian vein or the ovarian artery. This is supported by the results obtained by Parr et al. [29] and Kleemann et al. [36], who indicated that changes to the hormonal environment of the early embryo can influence subsequent development. Since ovarian venous progesterone can pass into the ovarian artery, via a counter-current mechanism [37], and a branch of this artery supplies the oviduct/uterus with blood [38], the actual progesterone supply to the uterus may be unrelated to the peripheral concentrations of this hormone. Thus, peripheral concentrations of progesterone may be of little importance to the developing embryo.
Undernutrition may act through changes in the distribution of progesterone in the endometrium. In an experiment designed to compare progesterone concentrations in the ovarian and jugular veins, and in the endometrial tissue of pregnant and nonpregnant ewes [13], pregnant ewes presented similar jugular concentrations of progesterone, but higher progesterone concentrations in both the ovarian vein and endometrial tissue than animals experiencing total absence of embryos by day 14 of pregnancy. These results do not prove that the difference in endometrial progesterone content cause pregnancy failure but they are consistent with the hypothesis that confirms the detrimental effects of progesterone during embryo development and suggest that the understanding of the effects of nutrition on pregnancy and embryonic wastage may be improved by measuring progesterone concentrations in the ovarian vein/or endometrium.

In spite of the extremely high concentrations of progesterone measured in the ovarian vein (1200-2000 ng.mL $\left.{ }^{-1}\right)$ and the uterine vein (13-46 ng. $\mathrm{mL}^{-1}$ ), no differences due to the level of nutrition in the delivery of progesterone from the ovary to the endometrium were observed on either day 5 [31], day 8 [20], day 10 or day 15 $[31,39]$ of pregnancy. Regarding the effect of the level of food intake on endometrial progesterone content, Lozano et al. [26] found no difference in endometrial progesterone content on day 4 of pregnancy in superovulated ewes and, similarly, there was no difference on day 9 [39] or day 10 of the cycle [31], in ewes fed diets providing different levels of energy. In a further study of the effect of undernutrition on the delivery of progesterone to the uterus, endometrial tissue samples were collected on day 5 and 10 of the cycle, from ewes fed 0.5 or $1.5 \mathrm{M}$ [31]. As previously reported, there was no effect of level of nutrition on progesterone concentrations in either ovarian or uterine veins on either day, 
although circulating progesterone concentrations were higher and endometrial levels were lower on day 5 of the cycle in ewes fed half of their maintenance requirements [31]. This finding provides a link between the known role of progesterone in embryo survival by the modulation of uterine function and the higher embryo losses found in undernourished ewes.

\section{EFFECT OF NUTRITION ON EMBRYO QUALITY AND DEVELOPMENT}

Both overfeeding and undernutrition have been described as detrimental for embryo development. Rhind et al. [35] observed an increased rate of ova wastage in ewes which had a restricted food intake (0.5 M) compared with adequately feeding $(1.5 \mathrm{M})$ during the 14 days prior to mating until slaughter 11 days after mating. Studies of embryos in vitro [40], demonstrated a reduction in the rate of development and viability of embryos collected on day 2 after fertilization with increasing donor feeding level during the period of oestrous synchronization. It was concluded that nutrition during oocyte maturation has important effects on embryo viability in superovulated ewes. Wallace et al. [41] found no effect of level of nutrition from day 0 to day 16 of the cycle on embryo survival and concluded that such effects were exerted before the embryo enters the uterus or after the embryo has successfully overcome luteolysis. Abecia et al. [20] observed a delay in the development of embryos collected from undernourished ewes 8 days after mating. Using ewes slaughtered on day 15 of pregnancy, Abecia et al. [39] reported significantly less embryos collected from restricted ewes reaching the stage of elongated blastocysts, although no differences in the number of blastocysts were recorded on day 9 of pregnancy. This was consistent with previous reports $[19,20,30]$, that indicated that the effect of undernutrition on pregnancy rate is only expressed from the second week of pregnancy.

The effects of protein level in the diet have also been studied to determine its effect on embryo development. Abecia et al. [20] found no effect of level of dietary protein on pregnancy rate 8 days after mating. However, Berardinelli et al. [42], feeding ewes with an excess of degradable protein intake (twice the requirements) during an oestrous cycle until surgery in the next cycle, observed impeded embryo transport on day 5 and thereafter, embryo transport and development through the oviduct was accelerated. On the contrary, McEvoy et al. [43], after collecting embryos from ewes supplemented or not with an excess of urea in the diet for 12 weeks, observed a delay in the development of the embryos collected from the supplemented ewes. They concluded that excess rumen degradable nitrogen in ewe diets elevates plasma urea and ammonia levels in utero, with an associated increase in embryo mortality. Nevertheless, metabolism appears to be upregulated in some embryos and, amongst those that survive fetal growth appears to be enhanced. Rhind et al. [14] reported a higher mean potential litter size, as determined at slaughter three weeks after mating, in ewes on a high intake (ad libitum) during the weeks before mating, in comparison with ewes on lower intakes (M).

This set of preliminary experiments led to the conclusion that the effects of undernutrition on embryo survival are not necessarily mediated through changes in ovarian function or progesterone delivery to the uterus, but may involve changes in the uterine environment resulting from different patterns of embryo-maternal signals.

\section{EFFECT ON UTERINE GENE EXPRESSION AND EMBRYO-MOTHER SIGNALING}

In ruminants, the establishment and maintenance of pregnancy results from 
signaling by the conceptus to the maternal system and requires progesterone from the corpus luteum, which is essential for the maintenance of pregnancy. Understanding of the factors that regulate the lifespan and function of the corpus luteum during pregnancy may have a major impact on reproductive success, since 25 to $55 \%$ of all mammalian embryos are lost during early pregnancy. This may be the result of failure of corpus luteum maintenance (for reviews see [44] and [45]). The process through which the regression of the corpus luteum (luteolysis) is blocked in early gestation in ruminants has been termed maternal recognition of pregnancy [46]. The luteolytic mechanism in ruminants comprises a positive feedback system involving the endometrial prostaglandin $\mathrm{F} 2 \alpha\left(\mathrm{PGF}_{2 \alpha}\right)$ and pituitary/luteal oxytocin. Oestrogens and progesterone, acting in the uterus via their nuclear receptors (ER and PR), are the main modulators of uterine function, and are implicated in the timing of luteolysis $[47,48]$. The ruminant embryo generates a signal (interferon-tau, IFN $\tau$ ) along the uterine horns during elongation that alters uterine gene expression in pathways not completely understood, modifying the episodic $\mathrm{PGF}_{2 \alpha}$ release that is responsible for the luteal regression (for review see [49]).

Most research on the effect of undernutrition on embryo survival has focused on pregnancy rates, embryo quality and development at stages of pregnancy, as mentioned above, and few studies have investigated the effect of nutrition on IFN $\tau$ produced by the embryo, endometrial $\mathrm{PGF}_{2 \alpha}$ secretion, and/or uterine gene expression.

Although based on results from a small number of animals, the results presented by Abecia et al. [39] provide the first evidence of an effect of maternal nutrition on IFN $\tau$ secretion from the conceptus and of $\mathrm{PGF}_{2 \alpha}$ production from the uterus. Embryos collected on day 15 of preg- nancy from ewes fed $0.5 \mathrm{M}$ secreted lower amounts of IFN $\tau$ in vitro, and endometrial tissue collected from those ewes secreted higher $\mathrm{PGF}_{2 \alpha}$ levels than ewes fed $1.5 \mathrm{M}$. This was accompanied by a reduction in embryo survival, as indicated by the ratio of embryos/number of corpora lutea. It was concluded that the lower pregnancy rates observed in underfed ewes could be mediated through altered signals of maternal recognition of pregnancy. In addition, the results by Lozano et al. [26] indicate that a low energy diet during early development of embryo collected from superovulated ewes increases the uterine production in vitro of $\mathrm{PGF}_{2 \alpha}$, which could lead to a poor uterine environment, thereby compromising the development of the embryo. However, in this study, no differences between groups were found with respect to IFN $\tau$ secretion by the conceptus.

It is important to note that before and during embryo elongation along the uterine horns, the embryo is living free in the uterine lumen and is completely dependent on uterine secretions for all its metabolic needs. Thus, the limiting factor of early embryonic mortality may be the mother's ability to promote embryo growth (motherto-embryo signaling). If around the time of maternal recognition of pregnancy in sheep (day 14), the embryo fails to deliver its signal (IFN $\tau)$ in an appropriate pattern, luteolysis follows and pregnancy is not maintained.

Progesterone is the main hormone involved in the maintenance of pregnancy since it is essential for the provision of a uterine environment appropriate for the successful development of the conceptus to term (for review see [49]). As previously discussed, undernourished ewes have greater plasma progesterone concentrations, but the concentration of this hormone in ovarian or uterine veins is unaffected by the plane of nutrition [31]. Nevertheless, a lower endometrial content of progesterone was found in 
undernourished ewes on day 5 of the oestrous cycle. Because receptor proteins concentrate the specific hormones in the target tissues [50], it is hypothesized that the lower endometrial progesterone content in undernourished ewes is attributable to a reduction in PR expression [51]. When an immunohistochemical technique was used to visualize PR immunoreactivity in endometrial sections collected from ewes fed 1.5 or $0.5 \mathrm{M}$, it was found that undernourished ewes had a lower average intensity of staining for PR (indicating a lower PR content) in most endometrial cell types on day 5 [51]; this may explain the lower endometrial content of progesterone on day 5 found in these ewes [31]. There were no differences in PR immunostaining amongst groups at day 10, an observation that parallels reports of progesterone endometrial content previously found in both groups on this day [31]. These results indicate that, in sheep, undernutrition provokes a reduction in the sensitivity of the endometrium to progesterone, i.e. there is a reduction in immunoreactivity of PR that may affect embryo survival. This is consistent with previous studies that showed that the same undernutrition treatment mentioned previously $(0.5 \mathrm{M})$ produced a higher percentage of morulae and early blastocysts, whereas all the embryos recovered from well fed ewes were expanded blastocysts [20].

In an attempt to extend these findings, the effects of undernutrition on the binding capacity, immunoreactivity and mRNA expression of endometrial ER and PR, have been investigated in non pregnant ewes fed to provide either $1.5 \mathrm{M}$ or $0.5 \mathrm{M}$ and slaughtered at days 5 or 14 of the oestrous cycle $[52,53]$. On day 5 , underfed ewes exhibited reduced uterine ER and PR binding capacities relative to the control group animals. On the contrary to our findings, other authors have reported an increase of endometrial ER binding in lean ovariectomized ewes $[17,54]$. The differ- ences are likely to be a consequence of different experimental designs (dynamic vs. static body condition variations; intact vs. ovariectomized animals). No effect of undernutrition was observed in the immunoreactivity and mRNA concentration of either receptor in the horn adjacent to the corpus luteum, indicating that the impaired uterine binding capacity of steroid receptors was not due to a reduction in the receptor gene expression. In summary, it is clear that in sheep, a state of undernutrition induces changes in the endometrial sensitivity to steroid hormones at early stages of pregnancy (early luteal phase: day 5) that could adversely alter uterine environment to the detriment of embryo survival. This could explain, at least in part, the greater embryo losses and retarded embryo development observed in undernourished animals by other authors $[12,20]$. From our findings [51, 53]; it seems unlikely that changes in endometrial sensitivity to steroids in later stages of gestation (e.g. day 10 or day 14 post-oestrus) contribute significantly to differences in pregnancy rates between undernourished and control ewes.

\section{FUTURE CONSIDERATIONS}

Although research on the effects of undernutrition on gonadotrophin and steroid secretion and follicular development has been documented, studies addressing the causes of poor embryo survival in undernourished ewes are scarce. Moreover, the molecular biology behind these processes is incipient and may involve nutritional signals (e.g. metabolic hormones) that acting directly on the uterus modify the embryo environment and thus, its survival. Examples of this are insulinlike growth factor-I (IGF-I) and leptin, the concentrations of which are reduced in undernourished ewes $[55,56]$. Receptors for IGF-I have been demonstrated 
in the ovine endometrium [57], although no evidence for the presence of the leptin receptor has been reported. However, a role for leptin in mouse implantation has been clearly demonstrated, with its actions being through endometrial receptors [58]. Moreover, IGF-I and leptin are capable of inducing activation of steroid hormone receptors in a ligand-independent manner $[59,60]$, and, through such effects, may contribute to the nutritional effects on steroid receptor activity. While research into the roles of these molecules and their receptors in the expression of effects of nutrition in ewes is in its infancy, a fundamental role for them in the establishment of pregnancy can be envisioned.

\section{ACKNOWLEDGEMENTS}

The authors wish to thank Dr Stewart Rhind for his revision of this manuscript. Some of the results presented have been derived from grants AGL2001-1817 and AGL200400432/GAN, from C.I.C.Y.T. (Spain). A.M. has been granted by International Foundation for Science (Grant IFS B/3025-2), and C.S. by Banco Santander Central Hispano-Universidad de Zaragoza.

\section{REFERENCES}

[1] Haresign W. The influence of nutrition on reproduction in the ewe. 2. Effects of undernutrition on pituitary-responsiveness to luteinizing-hormone-releasing hormone stimulation. Anim Prod 1981, 32: 257-260.

[2] Rhind SM. Nutrition: its effects on reproductive performance and its hormonal control in female sheep and goats. In: Speedy AW (Ed), Progress in Sheep and Goat Research, CAB International, Wallingford Oxon 0X10 8DE UK, 1992, p 131-151.

[3] Robinson JJ. Nutrition and reproduction. Anim Reprod Sci 1996, 42: 25-34.

[4] O'Callaghan D, Boland MP. Nutritional effects on ovulation, embryo development and the establishment of pregnancy in ruminants. Anim Sci 1999, 68: 299-314.
[5] Boland MP, Lonergan P, O'Callaghan D. Effect of nutrition on endocrine parameters, ovarian physiology, and oocyte and embryo development. Theriogenology 2001, 55: 1323-1340.

[6] Martin GB, Rodger J, Blache D. Nutritional and environmental effects on reproduction in small ruminants. Reprod Fertil Dev 2004, 16: 491-501.

[7] Coop IE. Effect of flushing on reproductive performance of ewes. J Agric Sci 1966, 67: 305.

[8] Russel AJF, Doney JM, Gunn RG. Subjective assessment of body fat in live sheep. J Agric Sci 1969, 72: 451-454.

[9] Rattray PV, Jagusch KT, Smith JF, Winn GW, Maclean KS. Getting an extra 20percent lambing from flushing ewes. NZ J Agr 1980, 141: 93.

[10] Brien FD, Cumming IA, Clarke IJ, Cocks CS. Role of plasma progesterone concentration in early-pregnancy of the ewe. Aust J Exp Agr 1981, 21: 562-565.

[11] Parr RA, Davis IF, Fairclough RJ, Miles MA. Overfeeding during early pregnancy reduces peripheral progesterone concentration and pregnancy rate in sheep. J Reprod Fertil 1987, 80: 317-320.

[12] Rhind SM, McKelvey WAC, McMillen S, Gunn RG, Elston DA. Effect of restricted food-intake, before and or after mating, on the reproductive-performance of greyface ewes. Anim Prod 1989, 48: 149-155.

[13] Abecia JA, Rhind SM, Goddard PJ, McMillen SR, Ahmadi S, Elston DA. Jugular and ovarian venous profiles of progesterone and associated endometrial progesterone concentrations in pregnant and non-pregnant ewes. Anim Sci 1996, 63: 229-234.

[14] Rhind SM, Leslie ID, Gunn RG, Doney JM. Plasma FSH, LH, prolactin and progesterone profiles of cheviot ewes with different levels of intake before and after mating, and associated effects on reproductive-performance. Anim Reprod Sci 1985, 8: 301-313.

[15] Allison AJ. Effect of nutritionally induced liveweight differences on ovulation rates and population of ovarian follicles in ewes. Theriogenology 1977, 8: 19-24.

[16] Rhind SM, McNeilly AS. Follicle populations, ovulation rates and plasma profiles of $\mathrm{lh}$, fsh and prolactin in Scottish blackface 
ewes in high and low-levels of body condition. Anim Reprod Sci 1986, 10: 105-115.

[17] Boukhliq R, Adams NR, Martin GB. Effect of nutrition on the balance of production of ovarian and pituitary hormones in ewes. Anim Reprod Sci 1996, 45: 59-70.

[18] Viñoles C, Forsberg M, Martin GB, Cajarville C, Repetto J, Meikle A. Shortterm nutritional supplementation of ewes in low body condition affects follicle development due to an increase in glucose and metabolic hormones. Reproduction, 2005, 129: 299-309.

[19] Abecia JA, Rhind SM, Bramley TA, McMillen SR. Steroid production and LH receptor concentrations of ovarian follicles and corpora lutea and associated rates of ova wastage in ewes given high and low levels of food intake before and after mating. Anim Sci 1995, 60: 57-62.

[20] Abecia JA, Lozano JM, Forcada F, Zarazaga L. Effect of the level of dietary energy and protein on embryo survival and progesterone production on day eight of pregnancy in Rasa Aragonesa ewes. Anim Reprod Sci 1997, 48: 209-218.

[21] Rhind SM, McNeilly AS. Effects of level of food intake on ovarian follicle number, size and steroidogenic capacity in the ewe. Anim Reprod Sci 1998, 52: 131-138.

[22] Kiyma Z, Alexander BM, Van Kirk EA, Murdoch WJ, Hallford DM, Moss GE. Effects of feed restriction on reproductive and metabolic hormones in ewes. J Anim Sci 2004, 82: 2548-2557.

[23] Adams NR, Abordi JA, Briegel JR, Sanders MR. Effect of diet on the clearance of estradiol-17-beta in the ewe. Biol Reprod 1994, 51: 668-674.

[24] Adams NR, Briegel JR, Sanders MR, Blackberry MA, Martin GB. Level of nutrition modulates the dynamics of oestradiol feedback on plasma FSH in ovariectomized ewes. Anim Reprod Sci 1997, 47: 59-70.

[25] Yaakub H, O'Callaghan D, Boland MP. In vitro embryo development from oocytes recovered from follicles in cattle in different diets. In: Agric Res Forum, 23rd Annual Research Meeting of Irish Grassland and Animal Production Association, 1997, p 267-268.

[26] Lozano JM, Lonergan P, Boland MP, O'Callaghan D. Influence of nutrition on the effectiveness of superovulation programmes in ewes: effect on oocyte quality and postfertilization development. Reproduction 2003, 125: 543-553.

[27] McEvoy TG, Robinson JJ, Aitken RP, Findlay PA, Palmer RM, Robertson IS. Dietary-induced suppression of preovulatory progesterone concentrations in superovulated ewes impairs the subsequent invivo and in-vitro development of their ova. Anim Reprod Sci 1995, 39: 89-107.

[28] Peura TT, Kleemann DO, Rudiger SR, Nattrass GS, McLaughlan CJ, Walker SK. Effect of nutrition of oocyte donor on the outcomes of somatic cell nuclear transfer in the sheep. Biol Reprod 2003, 68: 45-50.

[29] Lawson RAS, Cahill LP. Modification of the embryo-maternal relationship in ewes by progesterone treatment early in the oestrous cycle. J Reprod Fertil 1983, 67: 473-475.

[30] Parr RA, Cumming IA, Clarke IJ. Effect of maternal nutrition and plasma progesterone concentrations on survival and growth of the sheep embryo in early gestation. J Agric Sci Camb 1982, 98: 39-46.

[31] Lozano JM, Abecia JA, Forcada F, Zarazaga L, Alfaro B. Effect of undernutrition on the distribution of progesterone in the uterus of ewes during the luteal phase of the estrous cycle. Theriogenology 1998, 49: 539-546.

[32] Abecia JA, Lozano JM, Forcada F. A preliminary study on the effects of dietary energy and melatonin on the ex vivo production of progesterone and prostaglandin F-2 alpha by the corpora lutea and endometrial tissue of ewes. Vet Res Commun 1999, 23: 115-121.

[33] O'Callaghan D, Yaakub H, Hyttel P, Spicer LJ, Boland MP. Effect of nutrition and superovulation on oocyte morphology, follicular fluid composition and systemic hormone concentrations in ewes. J Reprod Fertil 2000, 118: 303-313.

[34] Parr RA. Nutrition-progesterone interactions during early pregnancy in sheep. Reprod Fertil Dev 1992, 4: 297-300.

[35] Rhind SM, McMillen S, Wetherill GZ, McKelvey WAC, Gunn RG. Effects of lowlevels of food-intake before and/or after mating on gonadotropin and progesterone profiles in greyface ewes. Anim Prod 1989, 49: 267-273.

[36] Kleemann DO, Walker SK, Seamark RF Enhanced fetal growth in sheep administered progesterone during the first three days of 
pregnancy. J Reprod Fertil 1994, 102: 411417.

[37] Einer-Jensen N, McCracken JA. The transfer of progesterone in the ovarian vascular pedicle of the sheep. Endocrinology 1981, 109: 685-690.

[38] Hunter, RHF. The fallopian tubes: their role in fertility and infertility, Springer Verlag, London, 1987, p 47.

[39] Abecia JA, Forcada F, Lozano JM. A preliminary report on the effect of dietary energy on prostaglandin F-2 alpha production in vitro, interferon-tau synthesis by the conceptus, endometrial progesterone concentration on days 9 and 15 of pregnancy and associated rates of embryo wastage in ewes. Theriogenology 1999, 52: 1203-1213.

[40] Creed J, McEvoy TG, Robinson JJ, Aitken RP, Palmer RM, Robertson I. The effect of preovulatory nutrition on the subsequent development of superovulated sheep ova in an in vitro culture system. Anim Prod 1994, 58: 82 .

[41] Wallace JM, Aitken RP, Cheyne MA. Effects of post-ovulation nutritional-status in ewes on early conceptus survival and growth invivo and luteotrophic protein secretion invitro. Reprod Fertil Dev 1994, 6: 253-259.

[42] Berardinelli JG, Weng J, Burfening PJ, Adair R. Effect of excess degradable intake protein on early embryonic development, ovarian steroids, and blood urea nitrogen on days 2 , 3,4 , and 5 of the estrous cycle in mature ewes. J Anim Sci 2001, 79: 193-199.

[43] McEvoy TG, Robinson JJ, Aitken RP, Findlay PA, Robertson IS. Dietary excesses of urea influence the viability and metabolism of preimplantation sheep embryos and may affect fetal growth among survivors. Anim Reprod Sci 1997, 47: 71-90.

[44] Niswender GD, Nett TM. In: Knobil E, Neill JD (Eds), The physiology of reproduction, Corpus luteum and its control in infraprimate species, Raven Press, New York, 1994, p 781-816.

[45] Thatcher WW, Guzeloglu A, Meikle A, Kamimura S, Bilby T, Kowalski AA, Badinga L, Pershing R, Bartolome J, Santos JEP. Regulation of embryo survival in cattle. Reproduction Suppl 2003, 61: 253-266.

[46] Short RV. Implantation and the maternal recognition of pregnancy. in: Wolstenholme G., O'Connor M. (Eds), Foetal Autonomy,
London, Ciba Foundation Churchill, 1969 p 2-26.

[47] Lamming GE, Wathes DC, Flint APF, Payne JH, Stevenson KR, Vallet JL. Local action of trophoblast interferons in suppression of the development of oxytocin and estradiol receptors in ovine endometrium. J Reprod Fertil 1995, 105: 165-175.

[48] Meikle A, Tasende C, Sosa C, Garófalo EG. The role of sex steroid receptors in sheep female reproductive physiology. Reprod Fertil Dev 2004, 16: 1-10.

[49] Spencer TE, Burghardt RC, Johnson GA, Bazer FW. Conceptus signals for establishment and maintenance of pregnancy. Anim Reprod Sci 2004, 82-83: 537-550.

[50] Clark JH, Schrader WT, O’Malley BW. Mechanisms of steroid hormones action. In: Wilson J.D., Foster D.W. (Eds), Textbook of Endocrinology, WB Saunders, Philadelphia, 1992, p 35-90.

[51] Sosa C, Lozano JM, Viñoles C, Acuña S Abecia JA, Forcada F, Forsberg M, Meikle A. Effect of plane of nutrition on endometrial sex steroid receptor expression in ewes. Anim Reprod Sci 2004, 84: 337-348.

[52] Sosa C, Viñoles C, Forsberg M, Valares JA, Forcada F, Abecia A, Meikle A. Effect of undernutrition on plasma and uterine levels of progesteron and estradiol and estrogen receptor endometrial expression in ewes. In: Proc 15th Int Congress on Animal Reproduction, Brazil, 2004, p 26.

[53] Sosa C, Abecia JA, Forcada F, Viñoles C, Tasende C, Valares JA, Palacín I, Martin GB, Meikle A. Effect of undernutrition on progesterone and oestrogen receptors and on endocrine profiles during the ovine oestrous cycle. Reprod Fertil Dev 2006, 18: 447-458.

[54] Adams NR, Ritar AJ. Measurement of estrogen receptors in the ovariectomized ewe is affected by body condition and secondary binding sites. Biol Reprod 1986, 35: 828832.

[55] Hua KM, Hodgkinson SCS, Bass JJ. Differential regulation of plasma levels of insulin-like growth factors-I and -II by nutrition, age and growth hormone treatment in sheep. J Endocrinol 1995, 147: 5078-5516.

[56] Bocquier F, Bonnet M, Faulconnier Y, Guerre-Milo M, Martin P, Chilliard Y. Effects of photoperiod and feeding level on perirenal adipose tissue metabolic activity 
and leptin synthesis in the ovariectomized ewe. Reprod Nutr Dev 1998, 38: 489-498.

[57] Stevenson KR, Gilmour RS, Wathes DC. Localization of insulin-like growth factor-I (IGF-I) and -II messenger ribonucleic acid and type 1 IGF receptors in the ovine uterus during the oestrous cycle and early pregnancy. Endocrinology 1994, 134: 16551664.

[58] González RR, Caballero-Campo P, Jasper M, Mercader A, Devoto L, Pellicer A, Simon C. Leptin and leptin receptor are expressed in the human endometrium and endometrial leptin secretion in regulated by the human blastocyst. J Clin Endocrinol Metab 2000, 85: 4883-4888.

[59] Flint APF, Sheldrick EL, Fisher PA. Ligandindependent activation of steroid receptors. Domest Anim Endocrinol 2002, 23: 13-24.

[60] Catalano S, Mauro L, Marisco S, Giordano C, Rizza P, Rago V, Montanaro D, Maggiolini M, Panno ML. Leptin induces, via ERK1/ERK2 signal, functional activation of estrogen receptor $\alpha$ in MCF-7 cells. J Biol Chem 2004, 279: 19908-19915.

To access this journal online: www.edpsciences.org 